\title{
Democracy and Environmental Degradation in the MENA Region (1972-2015)
}

\author{
Dr. Amira Tohamy
}

Eltayb is an Economics Lecturer at the Faculty of Commerce,

Zagazig University, Arab Republic of Egypt 



\section{Abstract}

This paper aims at studying the relationship between democracy and environmental degradation. The empirical analysis focuses on the relationship between two indicators of democracy: A combined index of political rights and civil liberties (as an independent variable) based on freedom house data; and an implied emission factor for $\mathrm{CO}_{2}$ (per capita) caused by the forest (as a dependent variable) in a crosssection data analysis at the World level (184 countries) in Year 2015, Both the cross -section ARDL Model and Panel VECM (Vector Error Correction Model) were used as well as Wald test, the Panel DOLS (Dynamic OLS) model and the FMOLS (Fully -Modified OLS) model.

After performing the Fisher-Johansen Test with the panel data of the MENA Region during the period (1972-2015). the study demonstrated that democracy had a positive effect in reducing environmental degradation in the long run- based on a cross-section data analysis of the whole world (184 countries) and the MENA Region. The study also revealed the direction of the relationship between democracy and environmental degradation in the MENA region which was emphasized by the Granger causality test .This means that more democracy reduces environmental pollution in both the short term and the long term. 
ملخص

تهدف هذه الورقة إلى دراسة العلاقة بين الايمقراطية و التدهور اليئي ، ركزالتحليل التطبيقي على دراسة العلاقةة بين متوسط نصيب الفرد من انبعاثات ثاني أكسيد الكريون التاتج عن الغابات. كمتغير تابع- وبين مونشري الديمقر اطية كمنغيرات مسنقلة:

A combined index of political rights and civil libertiesbased on frecdom house data

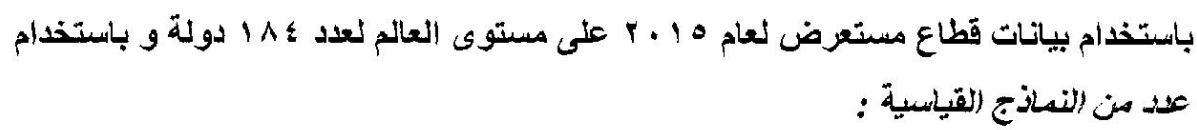

the cross - section ARDL Model and Panel VECM (Vector Error

Correction Model), the Panel DOLS (Dynamic OLS) model and the

FMOLS (Fully -Modified OLS) model.

وأسفرت الدراسة عن أن للايمقراطية أثر موجب في تقليل التدهور البيني .و بعد استخدام اختبار

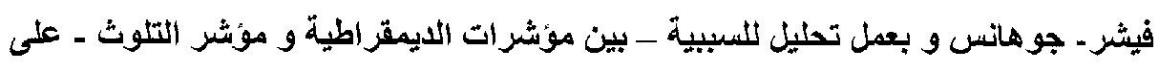

منطقة الثرق الأوسط و شمال إفريقيا خلا الفترة باستخدام بيانات سلسلة قطلعية خلال القترة

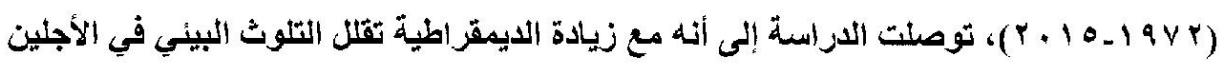
الطويل و الثقصير. 


\section{Introduction}

There is a growing global concern about environmental protection and pollution damage. The determinants of democracy are many, but at the present time, we increasingly hear of democratic and non-democratic systems and what is appropriate for the objectives to be achieved. So does democracy have an impact on the preservation of the environment and what are the indicators used to express democracy? Democracy is about much more than elections. By "democracy" we mean the existence of properly functioning institutions and the rule of law to protect people from all forms of discrimination and uphold their human rights; i.e., people having a say in the decisions that affect them threggh accountable, participative, representative and transparent political systems. Progress in this area can sometimes oceur quickly, even-upexpectedty; but it is more often the outcome of decades of serious wotk Fhe 2015 Foreign Commonwealth/Ofice Report, 2016).

The main Indicators of democracy ane the following: A combined index of political rights and civil libertjes, control of corruption, government effectiveness, political stability and absence of violence/terrorism, regulatory quality, rule/of lay and voice and accountability.

This study aims at assessing the impact of democracy on environmental degradation in the SArab countries and in 184 countries around the World. Following the Introduetion, the second part of this paper reviews previous related studies; while the third part includes the model data and description. The fourth part focuses on the model estimation based on the econometric analysis and discusses the estimation results. The fifth part presents the study findings and the conclusion.

\section{Previous literature}

The relationship between Democracy and Environmental Degradation has been the focus of numerous studies. We divided these studies into four types. 
The first type finds that democracy has a positive impact in reducing environmental degradation. The second group of studies maintains that democracy results in an increase of environmental degradation. The third group suggests that both sides might be right. The fourth group demonstrates that democracy has no effect on environmental degradation.

Examples of the first group are: Payne, R. (1995); Barrett, S. and Graddy, K. (2000); Farzin,Y. and Bond, C. (2006); and Torras and Boyce (1998).

Castiglionea, C. et.al., (2012) found that democratization makes citizens better informed, better organized, and better enabled to protest, and thus makes states and political entrepreneurs more responsive to demands for environmental protection. Didia, D. O. (1997), Li ,Q. and Reuveny, R. (2006) and Shandra, J. M. (2007), Povitkina, M. (2015): These studies founds that democracy has a positive effect in reducing environmental degradation, but that this effect depends upon the bureaucratic level.The second group includes fewer studies such as: Midlarsky, M. (1998.) and Congleton, R. D. (1992). Examples of the third group are: Buitenzorgy ,M. and Mol, A. P.J.(2011) who found evidence of an existing inverted U-shaped relationship between deforestation and democracy. Cropper and Griffiths (1994), suggested the presence of statistically significant EKCs for Latin America and Africa, but insignificant for Asia.

Examples of the fourth group are: Roberts, J.T. and Parks, B.C. (2007) who found that democracy had no effect on environmental degradation as measured by national pollution levels of $\mathrm{CO}_{2}$. .Scruggs, L. A. (1998) also found an insignificant relation between democracy and three environmental indicators (dissolved oxygen demand, fecal coliform and particulates emissions).

The present study examines statistically the relationship between democracy and environmental degradation in all countries of the World combined in 2015 and in the MENA countries during the period (1972-2015).

The rest of this paper is structured as follows: The third part of this paper includes the model description and data while the fourth 
part discusses the econometric analysis and the estimation results. The fifth part presents the conclusion.

\section{Model specification and data description}

This paper covers two cases: Firstly, the MENA region and secondly, 184 countries around the World.

\subsection{The case of the MENA region}

The study sample of the MENA region includes 21 countries, namely: Algeria, Bahrain, Djibouti, Egypt, Iran, Iraq, Israel, Jordan, Kuwait, Lebanon, Libya, Morocco, Oman, Qatar, Saudi Arabia, Sudan, Syria, The Arab Emirates, Yemen, Mauritania and Tunisia, Somalia.

In order to examine the relationship between democracy and environmental degradation in the MENA countries during the period (1972-2015), we used the following equation :

$$
(E / p)_{i t}=\alpha_{1}+\beta_{1}(\text { Democ. })+\beta_{2}(G D P / p)+\beta_{3}(\text { Gov. })+\varepsilon_{i t},
$$

where $\mathrm{E}$ represents emissions, $\mathrm{P}$ is population, $(\mathrm{E} / \mathrm{P})$ indicates the $\mathrm{CO}_{2}$ emissions per capita (metric ton per capita), and the control variables are: $(\mathrm{GDP} / \mathrm{P})$ for the gross domestic product per capita in $\$$, and (Gov.) to reflect the governance indicators namely: Control of Corruption, Voice and Accountability, Regulatory Quality, Rule of Law, Political Stability and Absence of Violence/Terrorism, Government Effectiveness, in addition to HDI.

Democ. is the independent variable (a combined index of political rights and civil liberties based on freedom house data), $\alpha_{1}$ is the intercept parameter, $\beta_{1}, \beta_{2}, \beta_{3}$ denote the parameters of the equation and $\varepsilon_{i t}$ is the random error term.

The data used were obtained from the World Bank indicators/ world bank/ www.worldbank.org, The International Financial Statistics ,The International Monetary Fund /www.IMF.org, and the Food and Agriculture Organization of the United Nations /www.fao.org. for the period 1972-2015. Table 1 shows the descriptive statistics of the variables. 


\section{Table 1: Descriptive statistics of the variables}

\begin{tabular}{|c|c|c|c|c|c|c|c|c|c|c|}
\hline & $\begin{array}{l}\mathbf{E} / \\
\mathbf{p}\end{array}$ & $\begin{array}{l}\text { GDP/ } \\
\mathbf{p}\end{array}$ & $\begin{array}{l}\text { Demo } \\
\text { c. }\end{array}$ & $\begin{array}{l}\text { Contro } \\
\text { l } \\
\text { of } \\
\text { Corrup } \\
\text { tion }\end{array}$ & $\begin{array}{l}\text { Govern } \\
\text { ment } \\
\text { Effective } \\
\text { ness }\end{array}$ & $\begin{array}{l}\text { politic } \\
\text { al } \\
\text { Stabili } \\
\text { ty } \\
\text { and } \\
\text { absen } \\
\text { ce } \\
\text { of } \\
\text { violen } \\
\text { ce } \\
\& \\
\text { terro- } \\
\text { rism }\end{array}$ & $\begin{array}{l}\text { Regula } \\
- \\
\text { tory } \\
\text { Qualit } \\
\text { y }\end{array}$ & $\begin{array}{l}\text { Rule } \\
\text { of } \\
\text { Law }\end{array}$ & $\begin{array}{l}\text { Voice } \\
\text { and } \\
\text { Accounta } \\
\text { bility }\end{array}$ & $\begin{array}{l}\text { HD } \\
\text { I }\end{array}$ \\
\hline Mean & 10.6 & 11805.3 & 5.38 & -0.2 & -0.21 & -0.56 & -0.28 & 0.22 & -0.94 & 0.67 \\
\hline $\begin{array}{l}\text { Maximu } \\
\text { m } \\
\end{array}$ & 64.5 & 94407.4 & 7 & 1.7 & 1.37 & 1.2 & 1.3 & 11 & 0.76 & 0.9 \\
\hline $\begin{array}{l}\text { Minimu } \\
\text { m }\end{array}$ & \begin{tabular}{|l|}
0.14 \\
139 \\
\end{tabular} & 290.44 & 1.5 & -1.58 & -1.77 & -3.18 & -1.7 & -1.9 & -1.94 & \begin{tabular}{|l|}
0.33 \\
0.14 \\
\end{tabular} \\
\hline Std. Dev. & 13.9 & 16484.4 & 1.224 & 0.74 & 0.7 & 0.98 & 0.76 & 2.2 & 0.57 & 0.14 \\
\hline
\end{tabular}

Table 1 shows that the mean of $\mathrm{CO}_{2}$ emissions is 10.6 metric tons per capita, with a maximum of about 64.5 metric tons and a minimum value of about 0.14 metric ton. The mean of per capita GDP is about $\$ 11805.3$, the maximum value is about $\$ 94407.4$ and the minimum is $\$ 290.44$. The mean of the Democracy Index is about 5.38 with a maximum about 7 and a minimum of 1.5. The mean of the control of corruption index is about -0.2 with a maximum of about 1.7 and a minimum value of -1.58 . The mean of the Government Effectiveness index is about -0.21 with a maximum of approximately 1.37 and a minimum of -1.77 . The mean of the Political Stability and the Absence of Violence/Terrorism index is about -0.56, a maximum about 1.2 and a minimum of -3.18 . The Regulatory Quality index has a mean of about -0.28 and ranges between a maximum of about 1.3 and a minimum of -1.7 . The mean of the Rule of Law index is about -0.22 with a maximum of about 11 and a minimum of -1.9. The Voice and Accountability index has a mean of about -0.94, a maximum of 0.76 and a minimum of -1.94 . The mean of the HDI index is about -0.67 with a maximum of about 0.9 and a minimum of 0.33 . 


\subsection{The case of the whole World (184 countries)- A cross-section data analysis}

The study sample of the whole World includes 184 countries .To examine the relationship between democracy and environmental degradation in the whole World in 2015, we used the following equation:

$$
(\mathrm{E})_{\mathrm{it}}=\alpha_{1}+\beta_{1} \text { (Democ.) }+\varepsilon_{\mathrm{it}} \text {, }
$$

where $\mathrm{E}$ is the implied emission factor for $\mathrm{CO}_{2}$ caused by the forest (measured in tons of $\mathrm{CO}_{2} / \mathrm{ha}$ ), Democ. is a combined index of political rights and civil liberties based on freedom house data, $\alpha_{1}$ is the intercept parameter while $\beta_{1}$ denotes the parameter of the equation and $\varepsilon_{\mathrm{it}}$ is the random error term.

All the used data were obtained from the World Bank indicators/ world bank/ www.worldbank.org, The International Financial Statistics, The International Monetary Fund /www.IMF.org and the Food and Agriculture Organization of the United Nations /www.fao.org. for 2015, Table 2 shows the descriptive statistics of the variables .

Table 2: Descriptive statistics of the variables

\begin{tabular}{|l|l|l|l|l|}
\hline Obs.781 & Mean & St.Dev. & Max. & Min. \\
\hline E & -1.39 & 2.99 & 6.86 & -24.3 \\
\hline Democ & 3.29 & 2 & 7 & 1 \\
\hline
\end{tabular}

Table 2 shows that the mean of $\mathrm{CO}_{2}$ emissions is -1.39 tons per hectare, with a maximum value of about 6.86 tons and a minimum value of about -24.3 tons. The mean of the Democracy Index is about 3.29 with a maximum of about 7 and a minimum of 1 .

\section{Econometric analysis and estimation of the results}

\subsection{The case of the MENA region}

In order to estimate the coefficients of the Mena region model, Im, Pesaran and Shin Unit Root test was applied to determine the order of integration of the variables .Table 2 displays the results. 
Table 3: Unit root test (Im, Pesaran and Shin) results:

\begin{tabular}{|c|c|c|c|}
\hline \hline \multirow{2}{*}{ Variable } & \multicolumn{2}{|c|}{ Level } & First difference \\
\hline & Intercept & $\begin{array}{c}\text { Intercept } \\
\text { and trend }\end{array}$ & Intercept \\
\hline \multirow{2}{*}{ E/P } & -1.95 & & $-17.9 * * *$ \\
& 0.2 & & 0.0000 \\
\hline GDP/P & 5.47 & & $-9.06 * * *$ \\
& 1.000 & & 0.0000 \\
\hline Democ. & 3.5 & & $-17.1758 * * *$ \\
& 0.66 & & 0.0000 \\
\hline
\end{tabular}

Note: $* * * * *, *$ indicate significance at $1 \%, 5 \%$ and $10 \%$ respectively.

The results in Table 3 indicate that the model variables $(E / P$, GDP/P, Democ.), are not stationary at the Level; but they are integrated of degree zero I(1) after taking the first difference for each of them, at the $1 \%$ significance level. These results make it possible to apply Panel VECM (Vector Error Correction model) , Wald test , Panel DOLS (Dynamic OLS) model and FMOLS(Fully -Modified OLS) model after performing the Fisher-Johansen Test (cointegration test) with panel data during the period (1972-2015).

The results of the Fisher-Johansen Test are shown in Table 4. 


\section{Table 4: Fisher-Johansen Test}

\begin{tabular}{|l|l|l|l|l|}
\hline \hline Test & $\begin{array}{l}\text { Statistic } \\
\text { Panel v-Statistic }\end{array}$ & $\begin{array}{l}\text { Prob. } \\
0.4077\end{array}$ & $\begin{array}{l}\text { Statistic. } \\
-0.392132\end{array}$ & $\begin{array}{l}\text { Prob. } \\
0.6525\end{array}$ \\
\hline Panel rho-Statistic & -0.085944 & 0.4658 & -2.420656 & $0.0077 * *$ \\
\hline Panel PP-Statistic & -2.652042 & $0.0040 * * *$ & -5.221284 & $0.0000 * * *$ \\
\hline $\begin{array}{l}\text { Panel ADF- } \\
\text { Statistic }\end{array}$ & -4.182333 & $0.0000 * * *$ & -5.715022 & $0.0000 * * *$ \\
\hline $\begin{array}{l}\text { Group rho- } \\
\text { Statistic }\end{array}$ & -1.27622 & 0.1009 & & \\
\hline $\begin{array}{l}\text { Group PP- } \\
\text { Statistic }\end{array}$ & -6.126115 & $0.0000 * * *$ & & \\
\hline $\begin{array}{l}\text { Group ADF- } \\
\text { Statistic }\end{array}$ & -6.523464 & $0.0000 * * *$ & & \\
\hline
\end{tabular}

Note: $* * * * * *$ indicate significance at $1 \%, 5 \%$ and $10 \%$ respectively.

From Table 4, we deduce that the null hypothesis is rejected and the alternative hypothesis denoting the existence of a long run equilibrium relationship (i.e., a co-integration relationship) between the variables of this model is accepted. Therefore the model variables (E/P, GDP/P, Democ.) are co-integrated in the long run. Thus we can complete the second step using VECM (vector Error Correction Model), Panel DOLS (Dynamic OLS) model and FMOLS (Fully Modified OLS). 
Table 5: VECM*, Causality-Test, Wald -Test $\left(\mathrm{c}_{4}, \mathrm{c}_{5}\right)$, cointegrating regression (DOLS, FMOLS), Panel Least Squares.

\begin{tabular}{|c|c|c|c|c|c|c|}
\hline Method & $\begin{array}{l}\text { Independent } \\
\text { Variables }\end{array}$ & Coefficient & $\begin{array}{l}\text { Std. } \\
\text { Error }\end{array}$ & $\begin{array}{l}\text { t- } \\
\text { Statistic }\end{array}$ & Prob. & $\mathbf{R}^{2}$ \\
\hline $\operatorname{VECM}{ }^{*}\left(c_{1}\right)$ & Democ. & $-0.035 * * *$ & 0.0056 & -6.284 & 0.0000 & \\
\hline Causality-Test & Democ. & & & 5.51 & 0.0042 & \\
\hline $\begin{array}{l}\text { Wald -Test }\left(c_{4}, c_{5}\right) \\
\text { Chi-square }\end{array}$ & Democ. & & & 11.4 & 0.0033 & \\
\hline DOLS & $\begin{array}{l}\text { Democ. } \\
\text { GDP/capita }\end{array}$ & $\begin{array}{l}-1.59 * * * \\
0.0002 * * *\end{array}$ & $\begin{array}{l}0.156 \\
3.9 \mathrm{E}-05\end{array}$ & $\begin{array}{l}-10.2 \\
6.07\end{array}$ & $\begin{array}{l}0.0000 \\
0.0000\end{array}$ & 0.33 \\
\hline FMOLS & $\begin{array}{l}\text { Democ. } \\
\text { GDP/capita }\end{array}$ & $\begin{array}{l}-1.62^{* * *} \\
0.00026^{* * *}\end{array}$ & $\begin{array}{l}0.13 \\
3.14 \mathrm{E}- \\
05 \\
\end{array}$ & $\begin{array}{l}-12.23 \\
8.17\end{array}$ & $\begin{array}{l}0.0000 \\
0.0000\end{array}$ & 0.26 \\
\hline $\begin{array}{l}\text { Panel Leas } \\
\text { Squares }\end{array}$ & $\begin{array}{l}\text { GDP/capita } \\
\text { Democ. } \\
\text { Control of } \\
\text { Corruption } \\
\text { HDI }\end{array}$ & $\begin{array}{l}0.000527 * * * \\
-0.988^{* * *} \\
-3.783^{* * *} \\
17.3 * * *\end{array}$ & $\begin{array}{l}3.6 \mathrm{E}-05 \\
0.132 \\
0.876 \\
4.74\end{array}$ & $\begin{array}{l}14.64 \\
-7.457 \\
-4.32 \\
3.65\end{array}$ & $\begin{array}{l}0.0000 \\
0.0000 \\
0.0000 \\
0.0003\end{array}$ & 0.72 \\
\hline $\begin{array}{l}\text { Panel Least } \\
\text { Squares }\end{array}$ & $\begin{array}{l}\text { GDP/capita } \\
\text { Democ. } \\
\text { Government } \\
\text { Effectiveness } \\
\text { HDI }\end{array}$ & $\begin{array}{l}0.00057 * * * \\
-3.033^{* * *} \\
-2.033^{*} \\
18.62 * * *\end{array}$ & $\begin{array}{l}3.88 E- \\
05 \\
0.46 \\
1.08 \\
5.12\end{array}$ & $\begin{array}{l}14.74 \\
-6.51 \\
-1.88 \\
3.64\end{array}$ & $\begin{array}{l}0.0000 \\
0.0000 \\
0.062 \\
0.0003\end{array}$ & 0.7 \\
\hline $\begin{array}{l}\text { Panel Least } \\
\text { Squares }\end{array}$ & $\begin{array}{l}\text { GDP/capita } \\
\text { Democ. } \\
\text { Political } \\
\text { Stability } \\
\text { andabsence of } \\
\text { Violence/Terr } \\
\text { orism } \\
\text { HDI }\end{array}$ & $-2.85744^{* * *}$ & 0.5486 & -5.2082 & 0.0000 & 0.7 \\
\hline
\end{tabular}




\begin{tabular}{|l|l|l|l|l|l|l|}
\hline \hline $\begin{array}{l}\text { Panel Least } \\
\text { Squares }\end{array}$ & $\begin{array}{l}\text { GDP/capita } \\
\text { Democ. } \\
\text { RegulatoryQu } \\
\text { ality } \\
\text { HDI }\end{array}$ & 1.57 & 1.01 & 1.55 & 0.123 & 0.66 \\
\hline $\begin{array}{l}\text { Panel Least } \\
\text { Squares }\end{array}$ & $\begin{array}{l}\text { GDP/capita } \\
\text { Democ. } \\
\text { Rule of Law } \\
\text { HDI }\end{array}$ & $-0.45 *$ & 0.24 & -1.84 & 0.067 & 0.67 \\
\hline $\begin{array}{l}\text { Panel Least } \\
\text { Squares }\end{array}$ & $\begin{array}{l}\text { GDP/capita } \\
\text { Democ. } \\
\text { Voice and } \\
\text { Accountability } \\
\text { HDI }\end{array}$ & $-5.73 * * *$ & 1.8 & -3.19 & 0.0016 & 0.67 \\
\hline
\end{tabular}

Note: $* * * * *, *$ indicate significance at $1 \%, 5 \%$ and $10 \%$ respectively.

Table 5 reveals the following:

- The Vector Error Correction Coefficient (VECM) is significant and negative denoting the existence of an error correction mechanism within the model and thus reflecting a stable relationship in the long run. This means that an inverse relationship exists between Democracy and carbon dioxide emissions in the long run and that such a relationship will not change.

- The value of chi-square resulting from Wald-test indicates the existence of a significant relationship between D [Democ.(-1)] and $\mathrm{D}$ [Democ.(-2)], thus confirming the long-term relationship between the variables.

- The Causality test confirms the existence of a causal relationship between the two variables, and the direction of the relationship from democracy to pollution.

- Table 5 also illustrates that using DOLS and FMOLS methods demonstrates that the per capita GDP has a significant positive effect on the carbon dioxide emissions per capita at the significance 
level of $1 \%$., while democracy has a significant negative effect at the same significance level.

- R-squared indicates that Democracy and per capita GDP explain about $33 \%$ of the changes in $\mathrm{CO}_{2}$ emissions.

- Because of the low value of the $\mathrm{R}^{2}$ coefficient, other indicators were added to express governance, namely: Control of corruption, government effectiveness, political stability and absence of violence/terrorism, regulatory quality, rule of law, voice and accountability, in addition to the human development index (HDI).

- Using the Panel Least Squares method gave the following results:

- All the indicators used to express democracy and governance have a negative effect on carbon dioxide emissions except the regulatory quality which has no effect. Control of corruption, political stability and absence of violence/terrorism have a significant negative effect at the significance level of $1 \%$ while the rule of law and government effectiveness share a significant negative effect at the significance level of $10 \%$.

Since environmental quality is mostly a public good, political freedom is considered favorable to environmental protection because non-democratic regimes tend to under-provide public goods including environmental quality. In non-democratic regimes, political elites monopolize production and hold a large share of national incomes and revenues. The implementation of rigorous environmental policies can lower production, income and consumption, which in turn, in an autocracy, would impose a higher cost on the elite than on the population, whereas the marginal benefit is uniform for both the elite and the population. Therefore, in an autocracy, elites are relatively less pro-environment than people are in a democracy. (Deacon, R., 2000 and Olson Mancur, 1993). 


\section{2: The case of a cross-section data analysis for the whole World} (184 countries)

\subsection{1: Co-integration test}

Table 6 shows the results of the co-integration test using the ARDL method.

Table 6: Bounds testing results

\begin{tabular}{|l|l|l|}
\hline \hline \multicolumn{2}{|l|}{ Regressors: $(\mathrm{K}=1)$} & F-statistic \\
\hline \multicolumn{2}{|l|}{$/ \boldsymbol{P}=\boldsymbol{f}(\boldsymbol{D e m} \boldsymbol{l}$. $)$, ARDL(4, 4, 4, 4) } & $\mathbf{8 9 . 4 2 2 0 6}$ \\
\hline $\begin{array}{l}\text { Significant } \\
\text { level }\end{array}$ & Critical value bounds & \\
\hline & \multicolumn{2}{|l|}{} \\
\hline $10 \%$ & Lower Critical Bounds(LCB) & Upper Critical Bounds (UCB) \\
\hline $5 \%$ & 2.44 & 3.28 \\
\hline $2.5 \%$ & 3.15 & 4.11 \\
\hline $1 \%$ & 3.88 & 4.92 \\
\hline \hline
\end{tabular}

Note: $* * *, \#, * *, *$ indicate significance at $1 \%, 2.5,5 \%$ and $10 \%$ respectively.$K$ indicates the numbers of independent variables in the model.

From the above-displayed results, it appears that the F-statistic value calculated for the model exceeds the corresponding Upper Critical Bound (UCB). Therefore, the null hypothesis is rejected and the alternative hypothesis denoting the existence of a long run equilibrium relationship (i.e., a co-integration relationship) between the variables of this model is accepted. 


\subsubsection{Estimation of the long and short-run coefficients of the variables and the error correction coefficient.}

Table 7: ARDL Regression and error correction model estimation

\begin{tabular}{|l|l|l|l|l|}
\hline Variable & Coefficient & Std. error & t-statistics & Prob. \\
\hline $\begin{array}{l}\text { Long-Run } \\
\text { Coefficients }\end{array}$ & & & & \\
\hline Democ. & $-0.3907 * * *$ & 0.067 & -5.9 & 0.0000 \\
\hline $\begin{array}{l}\text { Error correction } \\
\text { Coefficients } \\
\varphi_{\text {i }}\end{array}$ & $-1.01 * * *$ & 0.076 & -13.37 & 0.0000 \\
\hline $\begin{array}{l}\text { Short - Run } \\
\text { Coefficient }\end{array}$ & & & & \\
\hline D(Democ.) & $-\mathbf{0 . 0 0 5 9 3 3}$ & $\mathbf{0 . 0 9 9 5 5 4}$ & $\mathbf{- 0 . 0 5 9 6 0 1}$ & $\mathbf{0 . 9 5 2 5}$ \\
\hline D(Democ.(-1)) & $\mathbf{0 . 0 8 6 1 1 2}$ & $\mathbf{0 . 0 9 7 7 7 6}$ & $\mathbf{0 . 8 8 0 7 0 2}$ & $\mathbf{0 . 3 7 9 7}$ \\
\hline D(Democ.(-2)) & $\mathbf{0 . 1 7 9 9 5 9 *}$ & $\mathbf{0 . 0 9 8 9 7 0}$ & $\mathbf{1 . 8 1 8 2 4}$ & $\mathbf{0 . 0 7 0 7}$ \\
\hline
\end{tabular}

Note: $* * * * *, *$ indicate significance at $1 \%, 5 \%$ and $10 \%$ respectively.

Table 7 shows that Democracy has a significant and negative effect on the implied emission factor for $\mathrm{CO}_{2}$ caused by the forest $(E / P)$ at the significance level $1 \%$ in the long run. An increase of one unit in the value of the (Democ.) variable is accompanied by a decrease of 0.3907 unit on average in the value of $(E / P)$. It also appears that the error correction coefficient (ECM) is significant and negative denoting the existence of an error correction mechanism within the model and thus reflecting a stable relationship in the long run. This means that an inverse relationship exists between carbon dioxide emissions and Democracy in the long run and that such a relationship will not change. 


\section{Conclusion}

The main objective of this paper was to examine the relationship between Democracy and Environmental Degradation in the MENA Region. It was found that a negative relationship between Democracy and Environmental Degradation existed during the period 1972-2015 in the MENA region. This result was confirmed by the cross-section data analysis for the whole World (184 countries) in Year 2015 which means that an increase in democracy leads to a great reduction in carbon dioxide emissions. 


\section{Footnotes:}

(1) The Democracy Index indicates that: $1.0-2.5=$ free, $3.0-5=$ partly free, 5.5-7.0 $=$ not free.

(2) Equation : $\mathrm{D}(\mathrm{E} / \mathrm{p})=-0.035 *(\mathrm{E} / \mathrm{P}(-1)-2.57543226401 *$ Democ. $(-1)+$ $4.49301295429)+0.002 * \mathrm{D}(\mathrm{E} / \mathrm{P}(-1))-0.04 * \mathrm{D}(\mathrm{E} / \mathrm{P}(-2))+0.56 * \mathrm{D}$ (Democ.(-1)) $-0.35 * \mathrm{D}$ (Democ. $(-2))-0.07$ 


\section{References:}

- Barrett S. and Graddy K. (2000) "Freedom, growth, and the environment." Environment and Development Economics , vol.5, No.4,pp.433-456.

- Buitenzorgy, M. and Mol, A. P.J.(2011)" Does Democracy Lead to a Better Environment? Deforestation and the Democratic Transition Peak",

Environmental and Resource Economics, vol. 48,pp.59-70

- C. Castiglionea, B. D. Infantea,*, and J. Smirnovaa (2012) "Institutional enforcement, environmental quality and economic development. A panel VAR approach," Department of Economics, Statistics and Finance, University of Calabria, Italy.

- Cropper, M., \& Griffiths, C (1994) "The interaction of population growth and environmental quality”. American Economic Review,vol.84,No.2,pp.250-254.

- Congleton, R.D. (1992) “ Political institutions and pollution control ", The Review of Economics and Statistics, vol. 74, No. 3, pp.412-421

- Didia , D. O. (1997) “Democracy, political instability and tropical deforestation." Global Environmental Change, vol.7,No. 1,pp.63-76

- Farzin ,Y. and Bond, C. (2006) "Democracy and environmental quality.” Journal of Development Economics, vol. 81, No. 1, pp.213-235.

Http//www.fao.org.

Http//www.worldbank.org.

Http//www.IMF.org .

- Li, Q., Reuveny, R. (2006) “ Democracy and environmental degradation.” Journal of the International Studies Association, vol. 50,pp.935956.

- Payne, R. (1995) "Freedom and the environment." Journal of Democracy,vol.6,No.3, pp.41-55

- Povitkina, M.(2015) "Democracy, Bureaucratic capacity and environmental quality." (QOG) The Quality Of Government Institute, working paper series No.13

- Roberts, J., Parks B. C. (2007) “A climate of injustice, global inequality, NorthSouth politics and climate policy", MIT Press, Cambridge (Mass)

- Scruggs, L. (1998) "Political and economic inequality and the environment." Ecological Economics, No.26,vol.3 , pp. 259-275.

- Shandra, J. M. (2007) “The world polity and deforestation: a quantitative, crossnational analysis." International Journal of Social Research Methodology,vol.48,No.1,pp.5-27 
- The 2015 Foreign Commonwealth Office Report, (2016) "Human Rights \& Democracy" - Presented to Parliament by the Secretary of State for Foreign and Commonwealth Affairs by Command of Her Majesty The Queen of the U.K.

- Torras, M. and Boyce, J. K. (1998) "Income, inequality, and pollution: A reassessment of the Environmental Kuznets Curve." Ecological Economics ,vol.25,No.2,pp.147-160

- Midlarsky, M .(1998) "Democracy and the environment: An empirical assessment", Journal of Peace Research, vol.35,No.3,pp.341-361 